heat. The unnatural agglomeration of the 'gardens' in the can generated an exceedingly high temperature.

I then carried out some temperature measurements in a muund of the same species. The following measurements were made on October 11, 1949, in Ifakara (Tanganyika Territory) in the shade :

\begin{tabular}{|c|c|c|}
\hline Site of temp. measurement & 9 a.m. & 4 p.m. \\
\hline 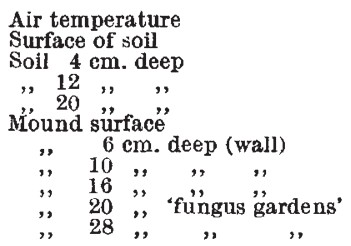 & $\begin{array}{l}27^{\circ} \mathrm{C} . \\
27 \\
25 \\
25 \\
25 \cdot 5 \\
27 \\
27 \\
28 \\
29 \\
30 \\
30 \cdot 5\end{array}$ & $\begin{array}{l}31^{\circ} \mathrm{C} \\
32 \\
29 \\
26 \cdot 5 \\
26 \\
31 \cdot 5 \\
29 \\
28 \\
29 \\
30 \\
30\end{array}$ \\
\hline
\end{tabular}

The relative humidity in the wall was about 85 per cent, in the 'fungus garden' area 95 per cent. The temperature in the interior of the nest where the 'fungus gardens' lie scattered is always about $30^{\circ} \mathrm{C}$. and remains very constant, at least in mounds standing in the shade of trees. In mounds exposed to the sun, the temperature in this region may rise by $2-3^{\circ} \mathrm{C}$. in the afternoon.

These observations indicate that the 'fungus gardens' play a large part in conditioning the microclimate of the nest cavity of termite mounds. They not only maintain a constantly high humidity, which may be brought about by the metabolism of the fungi ; but they also produce heat and play their part in maintaining a constant high temperature in the nest cavity. We suppose that this heat production is brought about by the activity of bacteria which may also be present in the "fungus gardens without fungi" found by Grassé and Noirot in the nests of Sphcerotermes sphoerothorax Sjöstedt ${ }^{6}$.

I wish to thank Prof. R. Geigy, director of the Swiss Tropical Institute, for making possible my participation in the Swiss East Africa expedition.

Swiss Tropical Institute,

M. LÜSCHER

Basel.

July 30 .

${ }^{1}$ Grassé, P. P., Ann. Sci. Nat. Zool., (11), 7, 115 (1945).

${ }^{2}$ Ghidini, G. M., Riv. Biol. Colon., 1, 261 (1938).

'Heim, R., Mém. Acad. Sci. Inst. France, 64 (1940).

"Lüscher, M., Acta Trop, 8, 161 (1949).

"Grassé, P. P., "Traité de Zoologie", 8 (Masson, Paris, 1949). "Grassé, P. P., and Noirot, Ch., Ann. Sci. Nat. Zool., (11), 10, 149

\section{Occurrence of a Trypanosome in Triatoma rubrofasciatus in Calcutta}

The occurrence of a trypanosome as a parasite in a triatoma has hitherto escaped notice in India. In 1909 Donovan, however, reported the presence of crithidia in the intestines of 'Triatoma rubrofasciatus in Madras. Triatoma rubrofasciatus, the common Indian cone-nosed bug, is found almost exclusively in and near human habitations. It is usually active at night, frequently feeding on human blood.

Of forty-five specimens collected from different parts of Calcutta and examined, thirty-six adult insects and nymphs harboured in their guts a large number of trypanosomes in various stages of development.

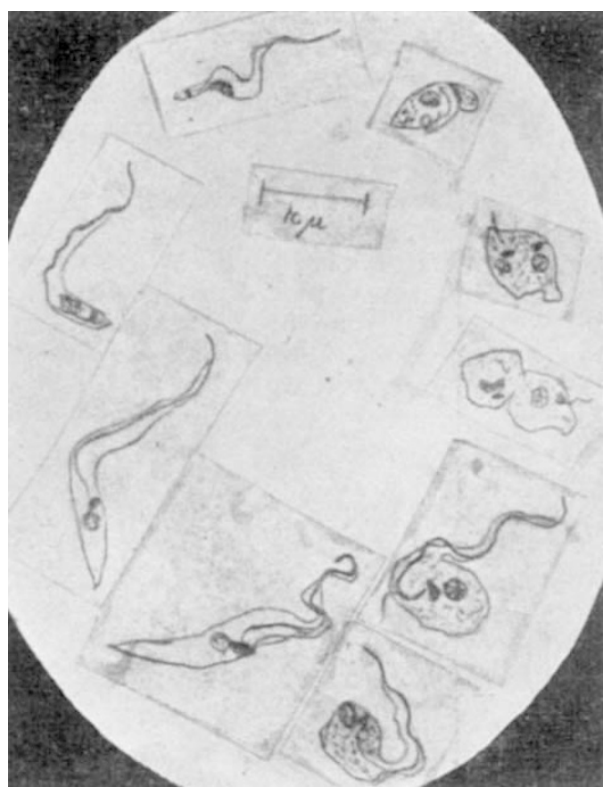

For the purpose of observation each insect was treated in the following manner. The entire aliment. ary canal with the salivary glands was carefully dissected out. Smears were taken from: $(a)$ teased salivary glands and the cesophagus; $(b)$ mid and upper part of the lower intestines; (c) lower intestine containing the fæcal matter; and (d) the hæmocele fluid.

All the smears were stained with combined Leishman and Giemsa stains and examined. It was found that (i) the hæmocœle fluid and the salivary glands and oesophagus revealed no parasites; (ii) the mid and lower sections of the intestine contained developmental forms of trypanosomes ; (iii) the fæcal matter from the lower part of the intestines and the rectum contained only crithidia and trypanosomes.

The accompanying illustration is from a camera lucida drawing of the parasites.

As illustrated, the trypanosome is long and slender, often C-shaped, the posterior end tapering sharply to a point. The width of the undulating membrane is variable, being very narrow in the young forms. The nucleus is oval in shape, and it lies nearer the posterior end. The parabasal body is somewhat elongated and the flagellum is rather small.

\begin{tabular}{|c|c|c|}
\hline \multicolumn{3}{|c|}{ MEASUREMENTS } \\
\hline & Average & Range \\
\hline $\begin{array}{l}\text { Length of the body } \\
\text { Length of the tlagellum } \\
\text { Totall length } \\
\text { Width of the body at nucleus } \\
\text { Diameter of the nucleus } \\
\text { Distance of the nucleus from the pos- } \\
\text { terior end } \\
\text { Distance between the nucleus and the } \\
\text { parabasal body } \\
\text { Width of the undulating membrane }\end{array}$ & $\begin{array}{r}23 \mu \\
11 \mu \\
34 \mu \\
5 \mu \\
2 \cdot 7 \mu \\
10 \cdot 2 \mu \\
4 \cdot 2 \mu \\
2 \cdot 2 \mu\end{array}$ & $\begin{array}{l}20-27 \mu \\
10-12 \mu \\
30-39 \mu \\
4 \cdot 9-5 \cdot 3 \mu \\
2 \cdot 4-3 \cdot 3 \mu \\
9-11 \cdot 6 \mu \\
3 \cdot 3-5 \cdot 3 \mu \\
2 \cdot 1-2 \cdot 4 \mu\end{array}$ \\
\hline
\end{tabular}

Further work on the subject is in progress.

S. M. Ghosh

T. C. Biswas

Department of Medical Entomology,

School of Tropical Medicine,

Calcutta.

Sept. 6.

2 Donovan, C., Trans. Bombay Med. Congress, 159 (1909). 